\section{Emphasis on 'aborigine rights'}

\section{Sydney}

FURTHER protests in Britain are being planned by the Tasmanian Aboriginal Centre following their success last month in obtaining the return of the mummified head of a Tasmanian Aboriginal from the Royal College of Surgeons in Dublin. Bob Weatherall and Michael Mansell, two representatives from the centre, have already mounted one protest in February outside the Natural History Museum which holds a large collection of aboriginal remains.

The head held in Dublin was that of the grandfather of Weatherall and was returned to him by the Australian Embassy in Dublin. The college had actually intended that the head go to the National Museum of Australia in Canberra and not to the Tasmanian Aboriginal Centre, according to Joseph Grace, Chief Administrator for the college. But the Australian Embassy in Dublin says that the Australian government supports the return of remains to their ancestors.

"Custodianship of remains is vested in the National Museum of Australia until such time as the appropriate aboriginal community is identified and accepts them. In this case $\mathrm{Mr}$ Weatherall was clearly related and there was no need for the remains to undergo an interim period at the museum", an embassy spokesperson said.

Although citizenship was only granted to Aborigines in 1967, the federal Aboriginal and Torres Strait Islanders Heritage Protection Act of 1984 provides for the protection of sacred objects, skeletal material and sites of significance. The federal act overrides legislation by the state and territories.

According to Fred Behr, spokesman for the Department of Aboriginal Affairs, the federal act can be used when the aboriginal community is unhappy with state legislation. "The federal minister can, in consultation with the aboriginal community, place a protection order on a site which overrules state legislation." The National Museum of Australia plays a safekeeping role until the federal minister, together with the aboriginal community, decides what to do with the remains.

That places the National Museum of Australia in a very different position from the British Natural History Museum which is prevented from giving up its collections by the British Museums Act of 1963 . A museum spokesman said at the time of the protest in February that it "would be a tragedy" to devalue the collection by dispersal.

In Australia, some collections are already being returned. In 1988, five aboriginal communities based around the Victoria-New South Wales border requested the return of the George Murray
Black collection from the Victorian Museum and the National Museum of Australia. The collection, the largest in Australia, was assembled in the $1920 \mathrm{~s}$ and 1930 s; part of it has already been returned and a spokesperson for the National Museum of Australia said the remainder will be returned "in the near future".

Australian policy has been hard on skeletal archaeologists who have abandoned the field in increasing numbers over the past decade. Peter Brown, a lecturer in palaeoanthropology at the University of New England in Armidale, is one researcher who left the study of Australian bones after finding it increasingly difficult to do fieldwork in Australia. Brown now works exlusively on remains in China and Europe and is encouraging his students to do the same. "Our (Australian) museum collections are poorly documented and it is impossible to do field work in this country. . . A Australia has a limited future as far as skeletal archaeology goes and there's no point training students in it if they can't get jobs." But Colin Pardoe, who is one of only five

\section{Washington}

'AQuarius', the world's most advanced underwater research station, is to be moved from the sea floor off St Croix in the US Virgin Islands because of damage inflicted by Hurricane Hugo.

According to the National Oceanic and Atmospheric Administration (NOAA), the storm destroyed the laboratory's surface support buoy and some onshore research facilities as it devastated the Caribbean last September and has left St Croix without critical support services, such as emergency medical care. But scientists involved with Aquarius say that the decision to move it was politically motivated and could hurt marine science in the region.

Aquarius is an 81-ton, trailer-like structure with a laboratory and living quarters that allows teams of up to six aquanautscientists to live and work on the sea floor for as long as two weeks. Typically stationed at a depth of 50 feet, the laboratory allows scientists to make scuba excursions to depths of 130 feet for as long as six hours at a time. Ordinarily, divers would be forced to restrict their dives to a few minutes or to undergo long decompression periods in order to return to the surface after dives to that depth.

Aquarius was first deployed in 1987 with the intention that it would eventually be moved. To make the project more attractive to the rest of Congress, the pro- skeletal archaeologists left in Australia, has a different view. He is a research fellow at the Institute for Aboriginal and Torres Strait Islanders Studies and says that any animosity between aboriginal communities and archaeologists arises out of the failure of archaeologists to return information, gained from the investigation of remains, to the aboriginal relatives.

Pardoe agrees with Brown that there is a feeling of pessimism in Australian archaeology. "Students are generally advised not to go into skeletal studies. There is a perception that soon there won't be anything to study. However, the future of Australian archaeology is clear. It involves the reality of aboriginal ownership, the continuation of cooperation and collaboration and the sharing of information in a way that can be understood by the aboriginal community", Pardoe said.

According to Jim Berg, coordinator of the Koori Heritage Trust in Melbourne, it is only white students who are being discouraged from pursuing skeletal studies: "We have our own people coming through the system (studying anthropology). We'd like our own history to be told by our own experts."

Tania Ewing

\title{
Stormy move for laboratory
}

ject's sponsor, former Senator Lowell Weicker (then a Republican from Connecticut), arranged for Aquarius to be movable to other marine sites. But now that the project is actually to relocate for the first time, marine scientists are concerned that valuable science opportunities will be lost. "If it were a strictly scientific decision, it would stay where it is", says Elizabeth Gladfelter, director of the West Indies Laboratory, which oversees Aquarius, "the laboratory was just realizing its full scientific potential at the site."

NOAA officials are considering other sites in the Caribbean, the Bahamas or the Florida Keys. The move is expected to take between six months and a year once a final destination site has been selected. But none of the sites contemplated is likely to provide the scientific opportunites of the current Salt River location, says former project director John Ogden. The existing site is on the floor of a submarine canyon with extensive coral reefs on both walls. Biologically interesting sites that are both deep and close to shore are relatively rare, he says.

Access to the West Indies Laboratory - regarded as the best-equipped marine biology lab in the Western Hemisphere is also seen as a significant loss. Despite $\$ 1.5$ million in damages during Hurricane Hugo, the laboratory is now back in operation while repairs continue.

G. Christopher Anderson 